\title{
Lysine utilization by growing pigs: simultaneous measurement of protein accretion and lysine oxidation
}

\author{
BY BEATRIX MNILK*, C. IAN HARRIS AND MALCOLM F. FULLER $\dagger$ \\ The Rowett Research Institute, Greenburn Road, Bucksburn, Aberdeen AB2 9 SB
}

(Received 6 April 1995 - Accepted 3 May 1995)

\begin{abstract}
Nitrogen retention and lysine oxidation were measured in growing pigs given diets which supplied $0,0.2$ or 0.8 of the lysine requirement, with other amino acids in relative excess. Eight groups of three female littermate pigs were used: one of each group was given each of the three diets. In half the pigs (four groups) $N$ retention was measured at body weights (W) of approximately 25,35 and $45 \mathrm{~kg}$. The other four littermate groups of three pigs were given the same three diets; when they reached $35 \mathrm{~kg} \mathrm{~W}$ they were given a continuous $(6 \mathrm{~h})$ primed infusion of $\mathrm{L}-\left[6-{ }^{3} \mathrm{H}\right]$ lysine. Lysine oxidation was estimated from the production of tritiated water. Rates of both $\mathrm{N}$ retention and lysine oxidation increased significantly with lysine intake; mean values $\left(\mathrm{g} / \mathrm{kg} \mathrm{W^{0.75 }}\right.$ per d) for the three diets respectively were for $\mathrm{N}$ retention, 0.00 , 0.32 and 1.22 , and for lysine oxidation $0.051,0.058$ and 0.078 . From the $\mathrm{N}$ balance results (assuming a constant lysine concentration in body protein) the efficiency of utilization of absorbed lysine was estimated to be 0-85; from the oxidation results (assuming lysine absorbed but not retained is oxidized) the estimate was 0.95 .
\end{abstract}

Amino acid requirement: Lysine utilization: Pig

Growth requires a balanced supply of all the amino acids used in body protein accretion. If any of the indispensable amino acids in the diet is deficient relative to the others it is conserved by mechanisms which limit its oxidation. However, even when the amino acid is completely absent from the diet, oxidation is not completely prevented and that irreducible minimum oxidation forms a major component of the maintenance requirement. Conversely, when the intake of an amino acid is excessive relative either to other amino acids or to the animal's capacity to utilize it for body protein accretion then oxidation is increased to prevent a potentially toxic accumulation of the free amino acid. Between these two extremes, the rate of amino acid oxidation is modulated according to the supply of, and demand for, the amino acid. The extent to which amino acids are oxidized at suboptimal intakes is an important determinant of the efficiency with which protein is utilized by growing animals. Amongst the amino acids it is commonly lysine which most limits the utilization of dietary protein. When lysine is the limiting amino acid it seems to be particularly well conserved (Yamashita \& Ashida, 1969). This metabolic sparing mechanism involves minimizing the activity of lysine $\alpha$-ketoglutarate reductase ( $E C$ 1.5.1.7; LKGR), the first enzyme in the main hepatic pathway of lysine oxidation (Chu \& Hegsted, 1976).

There are few direct measurements of lysine oxidation. This is due in part, no doubt, to the technical difficulties involved in the use of C-labelled amino acids, which requires collection and analysis of expired $\mathrm{CO}_{2}$; we have described previously a simpler procedure

\footnotetext{
* Present address: Sonderhäuserstrasse 83, O-5501 Nohra, Germany.

$\uparrow$ For reprints.
} 
using tritiated amino acids (Beckett et al. 1992). In the present paper we report direct measurements of lysine oxidation made by constant infusion of $L-\left[6-{ }^{3} \mathrm{H}\right] l y$ sine in pigs given diets either devoid of lysine or with one of two suboptimal intakes supplying approximately 25 or $75 \%$ of their requirements. The experiment included simultaneous measurements of protein utilization made by $\mathrm{N}$ balance.

\section{MATERIALS AND METHODS}

\section{Animals and diets}

The experiment included three diets (Table 1) supplying different concentrations of lysine. Measurements of $\mathrm{N}$ retention were made with twelve pigs at body weights (W) of 25, 35 and $45 \mathrm{~kg}$. Lysine oxidation was measured in another group of twelve pigs when they weighed $35 \mathrm{~kg}$.

Diet 1 was a completely synthetic diet containing the same amount of protein and essential amino acids as diet 2 but no lysine. Diet 3 was designed to meet the pig's requirement for protein and all indispensable amino acids (Wang \& Fuller, 1989; Fuller, 1991) except lysine. The lysine content was designed to provide $80 \%$ of the requirement. Diet 2 was formulated from the same ingredients as diets 1 and 3 and was designed to provide only $20 \%$ of the lysine requirement but with a relative excess $(25 \%)$ of protein and all other amino acids. All diets had approximately $15.5 \mathrm{MJ}$ digestible energy. The pigs were fed twice daily in two equal meals according to a feeding scale based on W $\left(98.5 \mathrm{~g} / \mathrm{kg} \mathrm{W}^{0.75}\right.$ providing a digestible energy intake equivalent to about 3.5 times the maintenance requirement). The ration for each pig was calculated on the basis of its $\mathrm{W}$ and its expected $\mathrm{W}$ gain so that, within the same balance period, all pigs got as nearly as possible the same amount of food.

Eight groups of three littermate female pigs, Large White $\times$ (Large White $\times$ Landrace), were used. When they weighed about $20 \mathrm{~kg}$, one was allocated to each of the three diets. Half these pigs (four groups of three littermates) were used in three successive N-balance experiments when they weighed 25,35 and $45 \mathrm{~kg}$. The other twelve pigs (another four groups of three littermates) were surgically prepared with two aortal PVC (NT ; Portex Ltd, Hyde, Kent) catheters introduced as described by Fuller et al. (1987). Catheter positions were confirmed by radiographic examination. After $10 \mathrm{~d}$ recovering from surgery these twelve pigs were given their appropriate diets until they were put into metabolism cages in preparation for the measurement of $\mathrm{N}$ balance and of lysine oxidation.

Pigs given diet 3 (high-protein diet with $80 \%$ of lysine requirement) and diet 2 (lowprotein diet with $20 \%$ of lysine requirement) had these diets throughout the experiment. However, because pigs on diet 1 (the low protein diet without lysine) did not grow, animals in this group were fed with diet 2 until they reached approximately $25 \mathrm{~kg} \mathrm{~W}$. Then they were given diet 1 for $5 \mathrm{~d}$ until the beginning of $\mathrm{N}$-balance period and for a further $6 \mathrm{~d}$ during the collection period. This process was repeated for measurements at 35 and $45 \mathrm{~kg}$.

The pigs were weighed at the same time every week and also before and after the $\mathrm{N}$ balance period. At $3 \mathrm{~d}$ before the first $\mathrm{N}$-balance period each pig was moved to a metabolism cage to allow it to acclimatize to its new environment, but they were moved only 1-2 $\mathrm{d}$ before the second and third periods. The day before urine and faeces collections were started bladder catheters were introduced. On each of the $6 \mathrm{~d}$ of the $\mathrm{N}$-balance period urine and faeces were collected separately, directly into $250 \mathrm{ml} 2 \mathrm{M}-\mathrm{H}_{2} \mathrm{SO}_{4}$. The $24 \mathrm{~h}$ urine collections were then pooled to form a single composite sample. The faeces were likewise pooled for $\mathrm{N}$ analysis. The pigs were moved to individual pens for a rest between the $\mathrm{N}$ balance periods. 
Table 1. Composition of the diets $(\mathrm{g} / \mathrm{kg})$

\begin{tabular}{|c|c|c|c|}
\hline Diet no.... & 1 & 2 & 3 \\
\hline Digestible energy $(\mathrm{MJ} / \mathrm{kg}$ ) & $16 \cdot 76$ & $15 \cdot 63$ & $15 \cdot 43$ \\
\hline Crude protein $(\mathrm{N} \times 6.25)$ & 31.66 & $40 \cdot 47$ & $160 \cdot 95$ \\
\hline 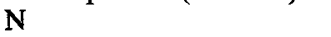 & 5.07 & 5.09 & $25 \cdot 69$ \\
\hline Apparent digestible $\mathbf{N}$ & 5.07 & $6 \cdot 47$ & $20 \cdot 29$ \\
\hline \multicolumn{4}{|l|}{ Ingredients } \\
\hline Barley & - & $170 \cdot 00$ & $625 \cdot 00$ \\
\hline Soyabean meal & - & $30 \cdot 00$ & $120 \cdot 00$ \\
\hline Dried skimmed milk & - & $15 \cdot 00$ & $80 \cdot 00$ \\
\hline Maize starch & 400.00 & $360 \cdot 00$ & - \\
\hline Glucose & $300 \cdot 00$ & $215 \cdot 00$ & - \\
\hline Sugar & $95 \cdot 00$ & 70.00 & - \\
\hline Cellulose & 60.00 & $45 \cdot 00$ & - \\
\hline Maize oil & 40.00 & 32.00 & 96.00 \\
\hline Minerals and vitamins* & $56 \cdot 40$ & 56.20 & 56.00 \\
\hline Aspartic acid & $17 \cdot 50$ & $2 \cdot 75$ & 10.00 \\
\hline Threonine & $1 \cdot 40$ & 0.35 & 1.50 \\
\hline Na glutamine & $20 \cdot 41$ & $3 \cdot 45$ & $13 \cdot 23$ \\
\hline Valine & 1.60 & 0.00 & 0.00 \\
\hline Cystine hydrochloride & 0.68 & 0.00 & 0.00 \\
\hline Methionine & 0.65 & $0 \cdot 30$ & $1 \cdot 40$ \\
\hline Isoleucine & 1.20 & 0.00 & 0.00 \\
\hline Leucine & $2 \cdot 26$ & $0 \cdot 00$ & 0.00 \\
\hline Tyrosine & $1 \cdot 10$ & $0 \cdot 00$ & 0.20 \\
\hline Phenylalanine & 1.35 & 0.00 & 0.00 \\
\hline Lysine & 0.00 & 0.08 & 0.00 \\
\hline Histidine & 0.92 & 0.00 & 0.00 \\
\hline Arginine & $2 \cdot 10$ & $0 \cdot 25$ & 0.50 \\
\hline Tryptophan & 0.38 & 0.05 & $0 \cdot 20$ \\
\hline Total & 1002.95 & $1000 \cdot 43$ & $1004 \cdot 03$ \\
\hline
\end{tabular}

* Containing $(\mathrm{mg} / \mathrm{kg})$ : Retinyl acetate and retinyl palmitate equivalent to retinol 3, cholecalciferol $90 \mu \mathrm{g}, \alpha$ tocopheryl acetate 15 , phylloquinone $1 \cdot 5$, pyridoxine $5 \cdot 73$, thiamin 2 , riboflavin $5 \cdot 41$, pantothenic acid 16.82 , nicotinic acid $29 \cdot 1$, cyanocobalamin 22.515 , inositol 150 , choline chloride $1.15 \mathrm{~g}$, biotin 2.5 , folic acid 2.75 , ascorbic acid 12, $\mathrm{NaCl} 3.5 \mathrm{~g}$, dicalcium phosphate $40 \mathrm{~g}, \mathrm{~K}_{2} \mathrm{CO}_{3} 7 \mathrm{~g}, \mathrm{FeSO}_{4}$ 96, Ca 362.5, $\mathrm{Fe} 100 ; \mathrm{Zn} \mathrm{100,} \mathrm{Mn} 40, \mathrm{Mg} 422$, $\mathrm{Cu} 175$, I 2; Co 1 , Se 0.25 .

\section{Oxidation measurements}

Tracer. L-[6- $\left.{ }^{3} \mathrm{H}\right] \mathrm{lysine}$ was purchased from Du Pont NEN Research Products (Stevenage, Herts.). The radiochemical purity was checked by TLC using the solvent system $n$ butane-acetic acid-water (15:4:10, by vol.) and was found to be greater than $99 \%$. The analytical purity was found to be $100 \%$ and the optical purity $\geqslant 98 \%$. After distillation of a diluted sample less than $0.01 \%$ of radioactivity was recovered in the distilled water as ${ }^{3} \mathrm{H}_{2} \mathrm{O}$.

Infusion procedures. On day 4 before the start of the $\mathrm{N}$-balance period the twice daily feeding regimen was changed to one of hourly feeding for all pigs with blood catheters to adapt them to continuous feeding. For this purpose an automatic feeder was used which delivered one-twenty-fourth of the day's food every hour.

The oxidation measurements were started immediately at the end of the N-balance period. For the measurement of total body water space approximately $7 \mathrm{~g}^{2} \mathrm{H}_{2} \mathrm{O}(98$ atom \%) was given over approximately $30 \mathrm{~s}$ via the shorter of the two catheters. Then a primed continuous infusion of L-[6- $\left.{ }^{3} \mathrm{H}\right] \mathrm{lysine}$ in physiological saline $(0 \cdot 15 \mathrm{M}-\mathrm{NaCl})$ was 
started; this was also given via the shorter catheter. The priming dose consisted of the equivalent of $1 \mathrm{~h}$ infusion $(2 \mathrm{ml})$ given over a period of $10.5 \mathrm{~min}(1 \mathrm{ml}$ given over $3 \mathrm{~min}$, followed by $1 \mathrm{ml}$ given over $7.5 \mathrm{~min}$ ). The infusion rate was then reduced to $2 \mathrm{ml} / \mathrm{h}$ for the next $6 \mathrm{~h}$. The total amount of labelled amino acid infused was approximately 3.0 MBq.

Blood samples $(10 \mathrm{ml})$ were taken after 2 and $6 \mathrm{~h}$ for the estimation of deuterium concentration and hourly for the estimation of the specific radioactivity (SRA) of free lysine in the blood. Blood samples $(10 \mathrm{ml})$ were taken at 2 and $6 \mathrm{~h}$ after the start of the infusion to determine the tritium labelling of the body water. Urine was collected by bladder catheter to estimate the amount of tritiated water excreted during the infusion period.

During the final minutes of the infusion the pigs were deeply anaesthetized with Euthesate (Willows Francis Veterinary, County Oak Way, Crawley, West Sussex) via the sampling catheter. Liver samples were taken by laparotomy and the pigs were killed by exsanguination. Liver samples were frozen immediately in liquid $\mathbf{N}_{2}$ for the estimation of saccharopine SRA. Other samples were rinsed in phosphate buffered saline (PBS) before freezing for the estimation of free lysine SRA.

\section{Sample preparation and analyses}

Nitrogen. The $\mathbf{N}$ concentration in the faeces, urine, and diets was estimated by the Kjeldahl method (Davidson et al. 1970; Association of Official Analytical Chemists, 1984) using the Technicon AutoAnalyzer.

Amino acid analysis. Hydrolysis of diet samples was carried out by refluxing with 6 M$\mathrm{HCl}$ at $137^{\circ}$. Cysteine and methionine were estimated after oxidation as described by Moore (1963). Amino acid concentrations were determined by ion-exchange chromatography using the Pharmacia LKB - Alpha plus (Pharmacia, Cambridge) except that cysteic acid and methionine sulphone were estimated on a Waters Picotag system (Waters, Milford, MA, US).

Specific radioactivity of lysine. Each blood sample $(10 \mathrm{ml})$ was mixed immediately with an equal volume of $1.5 \mathrm{M}$-perchloric acid (PCA) containing a norleucine standard and placed in ice-cold water. After at least 45 min the samples were centrifuged at $2000 \mathrm{~g}$ for $20 \mathrm{~min}$ at $4^{\circ}$. The supernatant fraction was titrated with $2 \mathrm{M}-\mathrm{KOH}$ to neutralize the PCA (to $\mathrm{pH} \mathrm{6.5).} \mathrm{After} \mathrm{standing} \mathrm{for} 30 \mathrm{~min}$ in ice-cold water the precipitated excess potassium perchlorate was removed by centrifugation and the supernatant fraction was frozen, freezedried and made up to $2 \mathrm{ml}$ with $0.1 \mathrm{M}-\mathrm{HCl}$. Samples were analysed on an amino acid analyser (resin LA49, $9 \times 260 \mathrm{~mm}$; The Locarte Co., London) in the preparative mode using 0.13 $\mathrm{M}$-trisodium citrate (for basic physiological-fluid amino acids using sodium salts

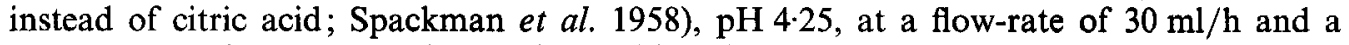
temperature of $29^{\circ}$. The lysine peak was identified in a microassay with $o$-phthaldehyde solution on a multiscan plate (D. Torrallardona, unpublished results) using Multiskan MCC/340 P version 2.31 (absorbance mode, continuous movement, filter $340 \mathrm{~nm}$ ), as described by Church et al. (1985), Goodno et al. (1981) and others (Roth, 1971; Roth \& Hampaï, 1973; Chen et al. 1979; Švedas et al. 1980; Rowlett \& Murphy, 1981). The corresponding vials with lysine were pooled. After acidifying the sample to $\mathrm{pH} 2$ the free amino acids (mainly lysine) were desalted on a cation-exchange column ( $\mathrm{H}^{+}$form $\mathrm{Zeo}$-carb 225 , mesh 50-100, dimension $16 \times 100 \mathrm{~mm}$ ) and eluted with $3 \mathrm{M}-\mathrm{NH}_{4} \mathrm{OH}$ into a roundbottomed flask. Samples were taken to near dryness under reduced pressure and washed twice with distilled water to remove as much of the $\mathrm{NH}_{3}$ as possible. After dissolving a $0.2 \mathrm{ml}$ portion of each sample (measured by weight) in $1.2 \mathrm{ml}$ distilled water the lysine concentration was measured using a Locarte amino acid analyser (resin Aminex A5; 
$6 \times 260 \mathrm{~mm}$; Biorad) using the same buffer, temperature and flow rate as before. The radioactivity in the remaining approximately $1 \mathrm{ml}$ of each sample, measured by weight, was counted in $10 \mathrm{ml}$ Optiphase ' $\mathrm{X}$ ' (FSA Laboratory Supplies, Loughborough, Leics.) using a Packard Tri-carb 1900CA liquid scintillation analyser (Packard Instruments, Downers Grove, IL, USA).

For the estimation of the SRA of free lysine in the liver, those liver samples which had been rinsed in PBS were homogenized with 1 M-PCA (sample-PCA 1:3, w/v) and treated in the same way as the blood samples described previously.

Identification of major catabolic products of lysine in liver. Approximately $50 \mathrm{~g}$ of each frozen liver sample was broken into small lumps under liquid $\mathrm{N}_{2}$, homogenized with $150 \mathrm{ml}$ of cold $1 \mathrm{M}-\mathrm{PCA}$, and centrifuged for $20 \mathrm{~min}$ at $10000 \mathrm{rev} . / \mathrm{min}$ and $4^{\circ}$ (centrifuge model MSE HS 25; MSE Centrifuges, Crawley, West Sussex). After neutralizing the PCA with 2 $\mathrm{M}-\mathrm{KOH}$ the precipitated perchlorate was removed by centrifugation, the supernatant fraction was freeze-dried and dissolved by washing out the flask twice with $25 \mathrm{ml}$ distilled water. Glycogen was removed by adding $100 \mathrm{ml}$ ethanol, precooled at $-20^{\circ}$ and left overnight in a tightly-sealed container or for at least $2 \mathrm{~h}$ at $-20^{\circ}$. The pellet obtained after centrifuging was washed once with precooled water-ethanol mixture $(1: 2, \mathrm{v} / \mathrm{v})$, the supernatant fractions were combined and evaporated to dryness. The sample was dissolved by washing out the flask three times with $50 \mathrm{ml} 0 \cdot 1 \mathrm{M}-\mathrm{HCl}$ and then applied to a $46 \times 200 \mathrm{~mm}$ column (Dowex resin $50 \times 8,200-400$ mesh, $\mathrm{H}^{+}$, washed with distilled water to neutral $\mathrm{pH}$ ). Three fractions were collected: (1) sample effluent plus $450 \mathrm{ml} 0.01 \mathrm{M}-\mathrm{HCl}$; (2) freshly prepared $4 \mathrm{M}-\mathrm{NH}_{4} \mathrm{OH}$ (1 litre) was applied and effluent was collected until the colour change in the resin covered about two-thirds of the resin bed (approximately $350 \mathrm{ml}$ ); this was taken as fraction 2 ; (3) fraction 3 consisted of the remaining effluent eluted by 4 M$\mathrm{NH}_{4} \mathrm{OH}$.

Fraction 3 was evaporated to dryness and approximately one-tenth of the sample was applied to a preparative column (resin Locarte 50 bed; $9 \times 480 \mathrm{~mm}$; buffer flow-rate $30 \mathrm{ml} / \mathrm{h}$ ) equilibrated with $0.3 \mathrm{M}$-lithium citrate $\mathrm{pH} 3.00$ and maintained at $36.5^{\circ}$. These conditions delayed the elution of saccharopine until after valine but before methionine. Material isolated under these conditions showed detectable radioactivity at approximately the position of saccharopine, but not entirely co-incident with unlabelled saccharopine.

Initially this absorption was explained as an isotope effect, already documented in ionexchange chromatography. However, observations mitigating against this interpretation are: (1) the information already available suggested that ${ }^{3} \mathrm{H}$-labelled amino acids usually eluted slightly earlier than their unlabelled counterparts (Nicholas et al. 1977) and (2) [methyl- ${ }^{3} \mathrm{H}_{3}$ ]methionine, as a model of the $\mathrm{L}-\left[6-{ }^{3} \mathrm{H}\right] \mathrm{lysine}$ used in this study, also showed this earlier elution of ${ }^{3} \mathrm{H}$-labelled compounds (results not shown).

Re-chromatography of the material at $\mathrm{pH} 3.10$ on a smaller column $(9 \times 250 \mathrm{~mm})$ showed that saccharopine was eluted earlier and well separated from the radioactivity which eluted in the position of pipecolic acid, another metabolite of lysine. There was no detectable radioactivity in the position of saccharopine. Unlabelled pipecolic acid was subsequently shown to coincide with the radioactivity at $\mathrm{pH} 3 \cdot 10$. However, there was insufficient activity to allow an accurate estimate to be made of the SRA of the pipecolic acid.

The remaining procedure was that used for SRA of lysine in blood and liver.

Specific radioactivity of water and deuterium enrichment. The blood samples for tritiated water analysis were centrifuged and the plasma was frozen until vacuum distillation, as described by Beckett (1989). A portion of each sample was used to determine the deuterium enrichment using a VG SIRA-10 (VG Isogas Ltd., Middlewich, Ches.) isotope-ratio mass spectrometer (Wong et al. 1987; Beckett, 1989) and the amount of radioactivity in a 
weighed amount was counted as described previously for the estimation of the SRA of water.

The increase in the SRA of body water was calculated either from a linear regression equation using the values for SRA of body water samples before infusion and at 2, 4, and $6 \mathrm{~h}$ after the start of infusion or the increase from time 0 (before infusion) to the end of infusion.

The plateau SRA of plasma lysine was estimated as the mean SRA of all samples identified graphically as plateau samples. From the areas under the curves of the timecourse of plasma lysine SRA the mean value over the whole period of infusion was also calculated and expressed as a portion of the plateau value (see below). However, sufficient data for this purpose were available for only five of the infusions.

\section{Calculations}

Lysine flux (Q) was calculated as:

$$
\mathrm{Q}(\mathrm{mmol} / \mathrm{h})=\text { infusion rate }(\text { disintegrations } / \mathrm{min}(\mathrm{dpm}) \text { per } \mathrm{h}) / \mathrm{SRA}_{\mathrm{p}}(\mathrm{dpm} / \mathrm{mmol}) \text {, }
$$

where $S_{R A}$ is the specific radioactivity of free lysine in the blood at plateau. A similar value was calculated on the basis of the liver lysine SRA. The production of tritiated water from $\mathrm{L}-\left[6-{ }^{3} \mathrm{H}\right]$ lysine was calculated from the increase in SRA of body water during the infusion multiplied by the tritium dilution volume determined by the dilution of the injected deuterium. The dilution space of deuterium (DS) is given by:

$$
\mathrm{DS}(\mathrm{kg})=(\mathrm{d} \times \mathrm{APEd} / \mathrm{MWd})(18.02 / \mathrm{APEbw}) \times 10^{-3},
$$

where APEd is atom percent excess of the given dose of ${ }^{2} \mathrm{H}_{2} \mathrm{O}$, APEbw is the calculated increase in atom \% excess of body water and $\mathrm{MWd}$ is the molecular weight of ${ }^{2} \mathrm{H}_{2} \mathrm{O}, 20 \cdot 016$.

The calculated total dilution space for tritium was corrected for the ratio between DS and tritium dilution space (Beckett, 1989) using the expression:

$$
\text { tritium dilution space }=1.0496(\mathrm{SE} 0.018) \times \mathrm{DS} \text {. }
$$

The rate of lysine oxidation was calculated from the rate of tritiated water production divided by the SRA of lysine. Because the liver is the primary site of lysine oxidation the SRA of free lysine in the liver was taken, in the absence of measurements of saccharopine SRA, as the best estimate of the precursor SRA. The rate of tritiated water production was calculated over the entire period of infusion, but, as this included production during the early part of the infusion before a plateau was attained, it was necessary to estimate the mean SRA of free lysine in the liver over the entire period of infusion. However, as only a final value of liver lysine SRA was obtained, it was assumed that average liver lysine SRA was the same proportion of its final value as mean plasma lysine SRA was of its final value.

\section{Statistical analysis}

The package GENSTAT 4.01 (Rothampsted Experimental Station, Harpenden, Hertfordshire) was used for statistical analyses.

\section{RESULTS \\ Weight gain}

Between 25 and $35 \mathrm{~kg}$, the average daily gains of pigs given diets 3 and 2 were respectively 0.50 and 0.21 (SE 0.023 ) kg/d. Pigs were given diet 1 only when they were close to their next measurement weight; at other times they were given diet 2 on which they gained on average $0.22 \mathrm{~kg} / \mathrm{d}$, essentially the same as those given diet 2 continuously. 
Table 2. Daily nitrogen retention of pigs given different daily lysine intakes*

(Values are from three successive $\mathrm{N}$ balance experiments with four pigs (series $\mathrm{N}$ ) and a single measurement with four pigs (series $\mathrm{I}$ ) in which lysine metabolism was also measured by trace kinetics)

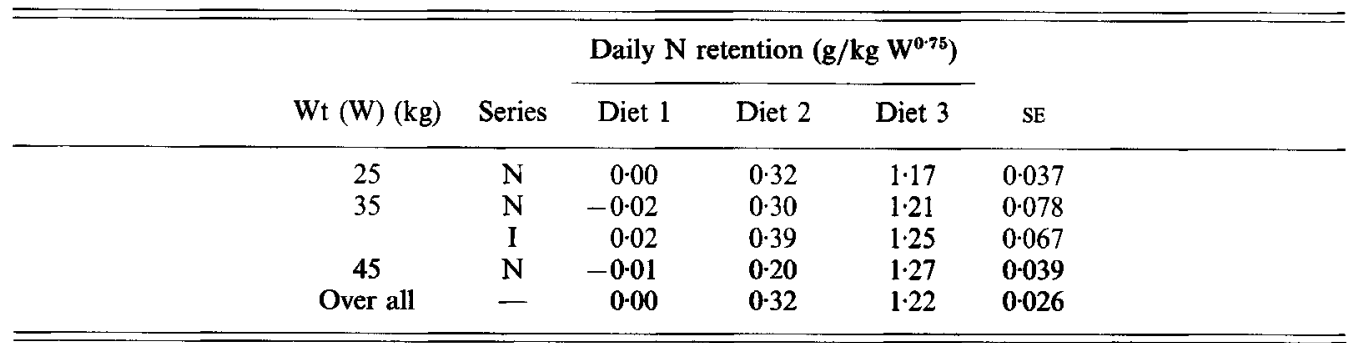

* Diet 1 , low-protein diet without lysine; diet 2 , low-protein diet with $20 \%$ lysine requirement; diet 3 , highprotein diet with $80 \%$ lysine requirement (for details of diets, see Table 1 and p. 58).

Table 3. Lysine kinetics in growing pigs of $35 \mathrm{~kg}$ given lysine-deficient diets with three concentrations of lysine*

(Body protein gained was assumed to have a lysine concentration of $65 \mathrm{mg} / \mathrm{g}$ )

\begin{tabular}{|c|c|c|c|c|}
\hline Diet no.... & 1 & 2 & 3 & $\mathrm{SE}$ \\
\hline Lysine absorbed $(\mathrm{g} / \mathrm{d})$ & 0 & $2 \cdot 28$ & $8 \cdot 84$ & - \\
\hline \multicolumn{5}{|l|}{ Final lysine SRA $(\mathrm{dpm} / \mathrm{nmol})$} \\
\hline Plasma & $13 \cdot 3$ & $10 \cdot 4$ & $5 \cdot 1\}$ & \\
\hline Liver & $9 \cdot 8$ & $7 \cdot 6$ & $4 \cdot 2\}$ & 0.88 \\
\hline \multicolumn{5}{|l|}{ Lysine flux $(\mathrm{g} / \mathrm{d})$} \\
\hline Using plasma SRA & $7 \cdot 8$ & $9 \cdot 1$ & $18 \cdot 7$ & 0.42 \\
\hline Using liver SRA & $8 \cdot 6$ & 11.9 & $22 \cdot 2$ & $2 \cdot 05$ \\
\hline Lysine oxidized (g/d) & 0.74 & $0 \cdot 84$ & $1 \cdot 12$ & 0.127 \\
\hline Whole-body protein synthesis $(\mathrm{g} / \mathrm{d})$ & 121 & 170 & 324 & - \\
\hline Whole-body protein degradation $(\mathrm{g} / \mathrm{d})$ & 133 & 148 & 212 & - \\
\hline \multicolumn{5}{|l|}{ Whole-body protein accretion $(\mathrm{g} / \mathrm{d})$} \\
\hline By difference & -12 & 22 & 112 & - \\
\hline From $\mathrm{N}$ balance & 0 & 28 & 109 & - \\
\hline
\end{tabular}

dpm, disintegrations/min; SRA, specific radioactivity.

* Diet 1, low-protein diet without lysine; diet 2, low-protein diet with $20 \%$ lysine requirement; diet 3 , highprotein diet with $80 \%$ lysine requirement (for details of diets, see Table 1 and p. 58).

\section{Nitrogen retention}

Rates of $\mathbf{N}$ retention are given in Table 2. There was no significant effect of $\mathbf{W}$ on the values expressed per $\mathrm{kg} \mathrm{W}^{0.75}$, the overall mean being $0.51 \mathrm{~g} / \mathrm{kg} \mathrm{W}^{0.75}$ per $\mathrm{d}$. There was no significant difference between the values at $35 \mathrm{~kg}$ for the pigs in the $\mathrm{N}$-balance experiment and the four used to measure lysine oxidation. For pigs on diet 3 with the highest lysine concentration, the mean rate of $\mathrm{N}$ retention was $1.22 \mathrm{~g} / \mathrm{kg} \mathrm{W}^{0.75}$ per $\mathrm{d}$, significantly higher than that with diet 2 . Pigs given diet 1 were, over all, in $\mathbf{N}$ equilibrium.

\section{Lysine flux and oxidation}

There was a significant difference in the SRA of free lysine in arterial plasma and in the liver (Table 3). Comparing samples taken at the end of the infusion, the mean plateau SRA of plasma lysine $(\mathrm{dpm} / \mathrm{nmol})$ was 9.58 , significantly higher than the SRA of free lysine in the 
liver $(7.20 ; P<0 \cdot 01)$. The mean plasma lysine SRA over the whole of the infusion (from the curve area) averaged 0.83 (SE 0.027 ) of the plateau value. This value was used for all pigs.

Whole-body lysine flux (Table 3) was calculated using both the plateau SRA of free lysine in the plasma and the SRA of free lysine in the liver. These values gave significantly different estimates but both showed similar effects of the diet, approximately doubling with increasing lysine intake. Table 3 also includes estimates of lysine oxidation, calculated from the liver free lysine SRA. Oxidation also increased significantly with increasing lysine intake.

\section{DISCUSSION}

Before discussing the nutritional aspects of the results it seems important to consider the potential errors in the estimation of lysine oxidation.

\section{The measurement of lysine oxidation}

The method we have used to measure oxidation requires that, when the amino acid is oxidized, the tritium label is transferred to water. In our previous studies with valine (Beckett et al. 1992) we used L-[3- $\left.{ }^{3} \mathrm{H}\right]$ valine from which the labelled $\mathrm{H}$ is transferred in oxidation to FAD. We found that our estimates of oxidation made with this tracer agreed closely with those made simultaneously with $\mathrm{L}-\left[1-{ }^{14} \mathrm{C}\right]$ valine $\left(r^{2} 0.95\right)$. L- $\left[6-{ }^{3} \mathrm{H}\right]$ lysine loses one labelled $\mathrm{H}$ to NAD when saccharopine is cleaved by saccharopine dehydrogenase (EC 1.5.1.9) to yield glutamate and 2-aminoadipate 6-semialdehyde; this in turn is converted to 2-amino adipate with the loss of the second labelled $\mathrm{H}$, in this case to NADP. If the NADPH is oxidized the second $\mathrm{H}$ also contributes to the labelling of water, but if it is used in synthetic processes there may be some sequestration of the isotope, resulting in an underestimate of lysine oxidation.

These measurements of lysine oxidation require that the SRA of both product and precursor be determined. Body water provides a large and fairly uniform pool of product but the SRA of free lysine differed considerably between extracellular (plasma) and intracellular (liver) pools. As LKGR, the first enzyme of lysine oxidation in the primary pathway via saccharopine, is in the mitochondrial matrix the SRA of the lysine that is oxidized may not be represented exactly by the total free lysine of the liver. To elucidate this possibility we attempted to isolate saccharopine in order to measure its SRA but were unable to detect it. This might suggest that in the pig LKGR and saccharopine dehydrogenase are so closely associated in the mitochondrial matrix that saccharopine is not released; indeed it has been suggested that in the liver of cattle (Markovitz \& Chuang, 1987) these activities are expressed by a single bifunctional enzyme and the same may be true for the pig. It seems unlikely that there would be a substantial difference in SRA between liver free lysine generally and that committed to oxidation in the liver mitochondria (which we attempted to establish by the isolation of saccharopine). However, although these two sources of uncertainty undoubtedly have some effect on the absolute values obtained, it seems unlikely that they are sufficient to alter the nutritional interpretation of the results.

\section{The utilization of lysine}

Despite the fact that diet 1 was essentially devoid of lysine the pigs given that diet apparently maintained $\mathrm{N}$ equilibrium at all three weights. In our earlier studies (Fuller $e t$ al. 1989) pigs given a lysine-free diet were in significant negative $\mathrm{N}$ balance $(-89 \mathrm{mg} /$ $\mathrm{kg} \mathrm{W}^{0.75}$ per $\mathrm{d}$, equivalent to $-1.28 \mathrm{~g} / \mathrm{d}$ for a $35 \mathrm{~kg}$ pig); we estimated the lysine requirement for maintenance in $35 \mathrm{~kg}$ pigs to be $0.52 \mathrm{~g} / \mathrm{d}$. This seeming discrepancy might 
be explained in one of two ways. First, it is well-known that $\mathrm{N}$ balance methods always tend to overestimate true $\mathrm{N}$ retention (as determined by comparative slaughter). However, our estimate of the lysine requirement for maintenance also was made from $\mathrm{N}$-balance experiments so this is unlikely to be the reason for the discrepancy.

Second, the animals in the present experiment were habituated to a low-lysine diet. Although they were given the lysine-free diet for $11 \mathrm{~d}$, which is comparable with the procedure in the experiments of Fuller et al. (1989), they were also given a severely lysinedeficient diet (diet 2) until that time. It seems possible that because of this adaptation their lysine requirement for maintenance may have been very low; indeed it has been reported that rats can live for more than 6 months on diets devoid of lysine (Bender, 1960). Although often explained as a peculiarly efficient conservation of lysine, this may be attributable to the absorption of lysine (and other amino acids) synthesized by gastrointestinal microflora. This usually neglected route of amino acid supply may be of quantitative importance in animals maintained on diets with low amino acid concentrations (Torrallardona et al. 1993, 1994, 1995).

The minimum rate of lysine oxidation observed, i.e. on the lysine-free diet, was $0.74 \mathrm{~g} / \mathrm{d}$, or $51 \mathrm{mg} / \mathrm{kg} \mathrm{W}^{0.75}$ per $\mathrm{d}$. This may be set beside the maintenance requirement which we estimated, in similar pigs, to be $38 \mathrm{mg} / \mathrm{kg} \mathrm{W}^{0-75}$ per d (Fuller et al. 1989). We have suggested that, although oxidation constitutes the major component of maintenance requirements, amino acid losses via the gastrointestinal tract are also important; from a number of estimates of the flow of lysine in digesta leaving the ileum, and on the assumption that none of this was subsequently re-absorbed, a mean daily loss of $28 \mathrm{mg} / \mathrm{kg} \mathrm{W}^{0.75}$ per d was estimated (Fuller, 1991). These two components, oxidation and gastrointestinal loss, are equivalent to $79 \mathrm{mg} / \mathrm{kg} \mathrm{W}^{0 \cdot 75}$ per $\mathrm{d}$. This is twice as much as our estimate of the total maintenance requirements. However, these calculations require some qualification. First, although studies in which protein or amino acids have been introduced into the large intestine suggest that little is absorbed, the large intestine has some capacity to absorb amino acids so it cannot be assumed that none of the lysine leaving the ileum is subsequently absorbed. Second, it is not yet clear how much of the lysine (or other amino acid) presumed lost in this way is included in our estimate of oxidation. If the lysine leaving the ileum is subsequently catabolized by the microflora of the large intestine some of the tritium label may appear in the body water, so it might be wrong to treat these two components as if they were completely independent. Third, the evidence that amino acids synthesized by gastrointestinal microflora may be absorbed in the upper gastrointestinal tract (Torrallardona et al. 1995) leads to the idea that amino acid equilibrium can be achieved with a dietary intake of an amino acid that is less than its metabolic disposal rate.

There was a significant increase in lysine oxidation with increasing lysine intake. This is in contrast to some models which suggest that, when amino acid intake is below the requirement, oxidation remains minimal and constant. The increment was, however, small. With an increase in the daily lysine absorbed from 0 to $8.44 \mathrm{~g}$, oxidation increased by only $0.38 \mathrm{~g}$. This is only $4.5 \%$ of the increase in lysine absorbed and implies that lysine is utilized for growth with a high efficiency, approximately $95 \%$. We have estimated lysine utilization also from the $\mathrm{N}$-balance experiments. The difference in $\mathrm{N}$ retention between diets 1 and 3 was $1.22 \mathrm{~g} / \mathrm{kg} \mathrm{W}^{0.75}$ per $\mathrm{d}$. If the body protein gained is assumed to have a $\mathrm{N}$ concentration of $160 \mathrm{mg} / \mathrm{g}$ and a lysine concentration of $65 \mathrm{mg} / \mathrm{g}$ the difference in lysine retention between these two diets would be $0.496 \mathrm{~g} / \mathrm{kg} \mathrm{W}^{0.75}$ per d. Related to the increment in lysine absorbed, this suggests a marginal efficiency of lysine utilization of 0.85 . This is very close to the value that Batterham et al. (1990) derived from a comparative-slaughter study with pigs given graded intakes of lysine. In that experiment the regression coefficient of daily body lysine gain on daily lysine apparently digested was 0.86 (SE 0.019). However, Langer 
\& Fuller (1995) gave growing pigs a series of lysine-deficient diets and calculated, using the same assumptions as those made previously, that the marginal utilization of lysine was 0.57 , much lower than the value deduced from the present measurements.

If we assume that an increment of absorbed lysine is equal to the sum of the increments of lysine retained and of lysine oxidized, our estimate of the efficiency of lysine retention of $0.95(1-0.045)$ is higher than even the highest estimate from retention studies of 0.86 (Batterham et al. 1990). This might suggest that our estimate of oxidation is in error by a factor of 3. However, the discrepancy could be explained by a proportionately much smaller error in the estimate of lysine retention computed from the $\mathrm{N}$ balances. This estimate is sensitive to the value assumed for the lysine concentration in the body protein retained. In the previous calculations a value of $65 \mathrm{mg} / \mathrm{g}$ was assumed: a higher value would diminish the difference between the estimates from $\mathrm{N}$ balance and from lysine kinetics. Furthermore, Batterham et al. (1990) and Gahl et al. (1992) reported that the lysine concentration in whole-body protein was reduced in pigs given a lysine-deficient diet. If their data are assumed to apply to the pigs in the present experiment the effect is to further increase the estimate of efficiency.

From the estimates of lysine absorbed (A) and oxidized (O), and from the lysine flux (Q), and assuming that whole-body protein of pigs contains $65 \mathrm{mg}$ lysine $/ \mathrm{g}$, rates of whole-body protein synthesis (S) and degradation (D) can be estimated using the equation $Q=S+O$ $=\mathrm{D}+\mathrm{A}$. The calculated rates are shown in Table 3. The difference between these rates, theoretically the rate of body protein accretion, is also given in Table 3 and compared with the rate calculated from the $\mathrm{N}$ balance values given in Table 2 . These show a difference of $-12 \mathrm{~g} / \mathrm{d}$ at the lowest lysine intake to $+3 \mathrm{~g} / \mathrm{d}$ at the highest.

The assumption that absorbed lysine is accounted for completely by oxidation and tissue accretion ignores other minor routes of disposal which may account for part of the difference. These include losses in skin and hair, conversion of lysine to other substances and urinary excretion of lysine and its metabolites. It is generally assumed, however, that these are small and increase little with amino acid intake. The definitive answer to the question of whether these two methods of estimating the efficiency of utilization of an amino acid agree or not must await the outcome of further studies in which all the relevant variables (absorption, oxidation, $\mathrm{N}$ retention and body amino acid composition) are measured simultaneously in the same animals. However, the present study suggests that in animals given amino acid-deficient diets efficiency is high, between 0.85 and 0.95 : furthermore, the development of a method to measure amino acid oxidation which does not require continuous confinement of the animal or respiration chambers to collect expired gases may allow future studies to be undertaken more readily.

This work was supported by the Scottish Office Agriculture and Fisheries Department.

\section{REFERENCES}

Association of the Official Analytical Chemists (1984). Official Methods of Analysis, 14th ed., p. 434 [S. Williams, editor]. Virginia: Association of the Official Analytical Chemists.

Batterham, E. S., Andersen, L. M., Baigent, D. R. \& White, E. (1990). Utilization of ileal digestible amino acids by growing pigs: effect of dietary lysine concentration on efficiency of lysine retention. British Journal of Nutrition 64, 81-94.

Beckett, P. R. (1989). Amino acid oxidation. PhD Thesis, University of Aberdeen.

Beckett, P. R., Cadenhead, A. \& Fuller, M. F. (1992). Valine oxidation: the synthesis and evaluation of L-(3- $\left.{ }^{3} \mathrm{H}\right)$ valine as a tracer in vivo. British Journal of Nutrition 68, 139-151.

Bender, A. E. (1960). Correlation of amino acid composition with nutritive value of proteins. Clinica Chimica Acta 5, 1-5.

Chen, R. F., Scott, C. \& Trepman, E. (1979). Fluorescence properties of $o$-phthaldialdehyde derivatives of amino acids. Biochimica et Biophysica Acta 576, 440-455. 
Chu, S.-H. W. \& Hegsted, D. M. (1976). Adaptive response of lysine and threonine degrading enzymes in adult rats. Journal of Nutrition 106, 1089-1096.

Church, F. C., Porter, D. H., Catignani, G. L. \& Swaisgood, H. E. (1985). An o-phthalaldehyde spectrophotometric assay for proteinases. Analytical Biochemistry 146, 343-348.

Davidson, J., Matheson, J. \& Boyne, A. W. (1970). The use of automation in determining nitrogen by the Kjeldahl method, with final calculation by computer. Analyst 95, 181-193.

Fuller, M. F. (1991). Present knowledge of amino acid requirements for maintenance and production: nonruminants. In Protein Metabolism and Nutrition. European Association of Animal Production Publication no. 59, pp. 116-126 [B. O. Eggum, S. Boisen, C. Børsting, A. Danfær, and T. Hvelplund, editors]. Tjele, Denmark: National Institute of Animal Science.

Fuller, M. F., Cadenhead, A., Mollison, G. \& Seve, B. (1987). Effects of the amount and quality of dietary protein on nitrogen metabolism and heat production in growing pigs. British Journal of Nutrition 58, $277-285$.

Fuller, M. F., McWilliam, R., Wang, T. C. \& Giles, L. R. (1989). The optimum dietary amino acid pattern for growing pigs. 2. Requirements for maintenance and for tissue protein accretion. British Journal of Nutrition $\mathbf{6 2}$, 255-267.

Gahl, M. J., Crenshaw, T. D. \& Benevenga, N. J. (1992). Amino acid composition in growing pigs fed graded levels of lysine. In Proceedings of the American Society of Animal Science, p. 66. Des Moines, IA: American Society of Animal Science.

Goodno, C. C., Swaisgood, H. E. \& Catignani, G. L. (1981). A fluorimetric assay for available lysine in proteins. Analytical Biochemistry 115, 203-211.

Langer, S. \& Fuller, M. F. (1995). Lysine utilization in growing pigs at three different levels of protein. Proceedings of the Nutrition Society 54, 64A.

Markovitz, P. J. \& Chuang, D. T. (1987). The bifunctional aminoadipic semialdehyde synthase in lysine degradation. Journal of Biological Chemistry 262, 9353-9358.

Moore, S. (1963). On the determination of cystine and cysteic acid. Journal of Biological Chemistry 238, $235-237$.

Nicholas, G. A., Lobley, G. E. \& Harris, C. I. (1977). Use of the constant infusion technique for measuring rates of protein synthesis in the New Zealand White rabbit. British Journal of Nutrition 38, 1-17.

Roth, M. (1971). Fluorescence reaction for amino acids. Analytical Chemistry 43, 880-882.

Roth, M. \& Hampaï, A. (1973). Column chromatography of amino acids with fluorescence detection. Journal of Chromatography 83, 353-356.

Rowlett, R. \& Murphy, J. (1981). A convenient spectrophotometric method for the kinetic analysis of the enzymatic hydrolysis of $N$-acyl peptides using phthaldialdehyde. Analytical Biochemistry 112, $163-169$.

Spackman, D. H., Stein, W. H. \& Moore, S. (1958). Chromatography of amino acids on sulphated polystyrene resins. Analytical Chemistry 30, 1185-1190.

Švedas, V.-J. K., Galaev, I. J., Borisov, I. L. \& Berezin, I. V. (1980). The interaction of amino acids with $a-$ phthaldialdehyde : a kinetic study and spectrophotometric assay of the reaction product. Analytical Biochemistry 101, 188-195.

Torrallardona, D., Harris, C. I., Milne, E. \& Fuller, M. F. (1993). Contribution of intestinal microflora to lysine requirements in nonruminants. Proceedings of the Nutrition Society 52, 153A.

Torrallardona, D., Harris, C. I., Milne, E. \& Fuller, M. F. (1994). The contribution of intestinal microflora to amino acid requirements in pigs. In Proceedings of the VIth International Symposium on Digestive Physiology in Pigs. European Association of Animal Production Publication no. 80, pp. 245-248 [W. B. Souffrant and H. Hagemeister, editors]. Dummerstorf: FBN.

Torrallardona, D., Harris, C. I., Milne, E. \& Fuller, M. F. (1995). Site of absorption of lysine synthesis by the gastrointestinal microflora of pigs. In Proceedings of the VII Symposium on Protein Metabolism and Nutrition, Portugal (In the press).

Wang, T. C. \& Fuller, M. F. (1989). The optimum dietary amino acid pattern for growing pigs. 1. Experiments by amino acid deletion. British Journal of Nutrition $62,77-89$.

Wong, W. W., Lee, L. S. \& Klein, P. D. (1987). Deuterium and oxygen-18 measurements on microliter samples of urine, plasma, saliva, and human milk. American Journal of Clinical Nutrition 45, 905-913.

Yamashita, K. \& Ashida, K. (1969). Lysine metabolism in rats fed lysine-free diet. Journal of Nutrition 99, 267-273. 